Bangladesh J. Bot. 49(4): 1071-1076, 2020 (December)

\title{
RESPONSE OF STRAWBERRY (FRAGARIA $\times$ ANANASSA DUCH.) TO PGPR INOCULATION
}

\author{
ANURADHA*, RK GoYal AND SS SINDHU ${ }^{1}$ \\ Department of Horticulture, CCS Haryana Agricultural University, \\ Hisar-125004, India
}

Keywords: Pseudomonas, Strawberry, Growth, Quality, Yield

\begin{abstract}
Investigation was carried out to study the effect of Pseudomonas strains on growth, yield and quality of strawberry cv. Chandler. The growth yield and quality of fruits were significantly influenced by various Pseudomonas strains. Root inoculations with selected bacteria significantly increased yield per plant (1.00 $26.89 \%)$ and average fruit weight $(0.64-11.89 \%)$ compared to control. Regarding various physico-chemical characters, viz. TSS, acidity, ascorbic acid and anthocyanin content of fruits, inoculation of Pseudomonas strain CP109 exhibited significantly enhanced values. The results indicated that inoculation with Pseudomonas strains could be an ecofriendly and cost-effective technology for improving the growth, yield and quality of strawberry.
\end{abstract}

\section{Introduction}

Strawberry (Fragaria $\times$ ananassa Duch.) is one of the perennial herbs, which is gaining popularity all over the world due to its high nutritive value and delicious taste. Strawberry fruits are very popular due to antioxidants having scavenging capacity against free radicals and contain a number of health promoting substances like carotenoids, phenols, flavonoids and dietary glutathionine (Singh et al. 2008). In India, because of its early duration, remunerative prices and higher economic return, it has become favourite fruit among the growers during the last decade. Further, availability of day neutral and high yielding varieties has resulted in phenomenal increase in its area and production (Paramanick et al. 2005). Strawberry is a shallow rooted herbaceous plant, of which, 50 - $90 \%$ of the root system is confined to upper $15 \mathrm{~cm}$ soil. Therefore, fertility, moisture, drainage and microbial status in upper soil layer have a great impact on growth, development, fruit yield, quality and production of runners. The modern strawberry cultivation that warrants high yield and quality requires extensive use of chemical fertilizers, which not only disrupt the balance of nature but also reduce economic efficiency (Wolfe and Patz 2002). Moreover, indiscriminate use of chemical fertilizers causes pollution of soil, air and water as well as human health hazard. This situation emphasized the need for the development of alternate production systems, which are environment friendly and is more judicious to manage the soil health.

Use of natural products like biofertilizers in crop cultivation will help in safeguarding the soil health and the quality of crop (Choudhary and Trivedi 2008). More recently, the use of plant growth promoting rhizobacteria has been exploited in fruit crops and they have proved to be a major tool in fruit production (Sindhu et al. 2010). The plant rhizosphere bacteria belonging to the genera Pseudomonas and Bacillus have been recognized as early root colonizers, which enhance plant growth by increasing seed emergence, plant weight and crop yield. Application of plant growth promoting rhizobacteria (PGPR) plays a potential role in increasing nutrients availability

*Author for correspondence: <anuradha2917@gmail.com>. ${ }^{1}$ Department of Microbiology, CCS Haryana Agricultural University, Hisar, 125004, India. 
and improving environment quality. Keeping all these aspects in view, the present investigation was carried out to find out ecofriendly technology for strawberry cultivation to boost up the productivity with minimal use of chemical fertilizers.

\section{Materials and Methods}

The experiment was conducted at Hi-tech greenhouse and in Post-harvest laboratory of the Department of Horticulture, CCS Haryana Agricultural University, Hisar (Haryana) during the years 2016 - 2017 and 2017 - 2018. Hisar region is characterized by semi-arid climate with hot and dry summer and cold winter. The soil of experimental plot was sandy in texture, low in

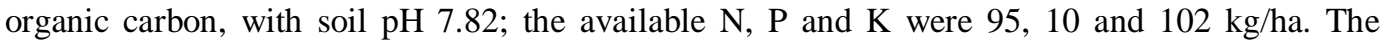
experiment was laid out in CRD with five treatments and four replications. The recommended doses of $\mathrm{P}$ and $\mathrm{K}$ were applied at the time of pot filling. The twelve inch size pots were taken and each pot filled with five kg soil and solar solarization method was used for sterilization of soil. The treatments used for the investigation were: $\mathrm{T}_{0}=\mathrm{JMM} 19, \mathrm{~T}_{1}=\mathrm{WHA} 87, \mathrm{~T}_{2}=\mathrm{CP} 109, \mathrm{~T}_{3}=$ HMM65 and $\mathrm{T}_{4}=$ Control (No Pseudomonas strain). Each of the treatments received $75 \%$ of recommended doses of fertilizers which were applied after planting of strawberry runners in the respective pots.

Observations on various growth and yield characters were recorded by using standard methods. Ten berries from each treatment were randomly selected to record the data on physicochemical characters. Crown diameter and fruit size was recorded by measuring length and breadth using the digital Vernier calipers, whereas fruit weight was taken using top pan digital balance. Total soluble solids were determined with Zeiss hand Brix refractometer $\left(0-32^{\circ} \mathrm{Brix}\right)$. The titratable acidity and ascorbic acid were determined by method as suggested in AOAC (1990). Anthocyanin content was measured using $\mathrm{pH}$ differential method. The results of yield attributes and yields showed similar trend during the years 2016 - 2017 and 2017 - 2018; therefore, pooled analysis of data was carried out. All the data were subjected to analysis using the OP STAT Software (Sheoran 2004) at 5\% probability level to compare the mean differences.

\section{Results and Discussion}

Pseudomonas sp. is widespread bacteria in agricultural soils and has many beneficial traits that make them well-matched as PGPR. The most effective strains of Pseudomonas are Gram negative, motile, rod shaped bacteria and have various phytobeneficial traits. Their plant growth promoting activities include production of IAA, HCN, siderophores, protease, antimicrobials and phosphate solubilizing enzymes (Kumari et al. 2015). Application of biofertilizers plays an important role in augmenting the yield parameters in different crops. Plant growth promoting rhizobacteria play an important role in enhancing plant growth and yield through a wide variety of mechanisms (Sindhu and Sharma 2019).

The results of present investigation indicated that root inoculation of strawberry plants with different Pseudomonas strains significantly promoted all the growth parameters, i.e., plant height, number of leaves, plant spread, appearance of the first flower, fresh weight of plant, dry weight of plant and number of runners per plant, but growth responses were found strain specific. The data recorded on the effect of different strains of Pseudomonas on growth parameters are presented in Table 1. The maximum plant height $(12.28 \mathrm{~cm})$, spread $(22.39 \mathrm{~cm})$, and number of leaves per plant (11.07), crown diameter (12.06 mm), fresh weight $(42.80 \mathrm{~g})$ and dry weight $(11.73 \mathrm{~g})$ of plant with minimum number of days (81.00 days) to flower in strawberry plants were recorded, when the plants were inoculated with CP109, followed by WHA87. Similar results were observed by Wani et al. (2007) who reported that Pseudomonas spp. secrete organic acids and enzymes that 
act as mineralization of immobile form of phosphates and it also produces amino acids, vitamins and growth-promoting substances, which promote plants growth, De Silva et al. (2000) reported that stem diameter increased with the application of Pseudomonas fluorescence Pf5 in high bush blue berry. Marques et al. (2010) found that Pseudomonas also plays a decisive role in plant growth promotion through reduction of ethylene production by synthesizing 1-aminocyclopropane-1-carboxylate (ACC) deaminase enzyme and this enzyme modulates the level of ethylene by hydrolyzing ACC in ammonia and $\alpha$-ketobutyrate (Khandelwal and Sindhu 2013).

Table 1. Effect of different Pseudomonas strains on growth of strawberry plants.

\begin{tabular}{lcccccccc}
\hline $\begin{array}{l}\text { Treatment/ } \\
\text { observations }\end{array}$ & $\begin{array}{c}\text { Plant } \\
\text { height } \\
(\mathrm{cm})\end{array}$ & $\begin{array}{c}\text { Plant } \\
\text { spread } \\
(\mathrm{cm})\end{array}$ & $\begin{array}{c}\text { Crown } \\
\text { diam. } \\
(\mathrm{mm})\end{array}$ & $\begin{array}{c}\text { No. of } \\
\text { leaves/ } \\
\text { plant }\end{array}$ & $\begin{array}{c}\text { Appearance } \\
\text { of the first } \\
\text { flower (days) }\end{array}$ & $\begin{array}{c}\text { Fresh wt. } \\
\text { of plant } \\
(\mathrm{g})\end{array}$ & $\begin{array}{c}\text { Dry wt. } \\
\text { of plant } \\
(\mathrm{g})\end{array}$ & $\begin{array}{c}\text { No. of } \\
\text { runners/ } \\
\text { plant }\end{array}$ \\
\hline $\mathrm{T}_{0}$ & 11.43 & 20.95 & 11.22 & 10.07 & 84.5 & 40.38 & 10.84 & 5.5 \\
$\mathrm{~T}_{1}$ & 11.7 & 21.58 & 11.5 & 10.4 & 84.38 & 41.08 & 11.21 & 6.5 \\
$\mathrm{~T}_{2}$ & 12.28 & 22.39 & 12.06 & 11.07 & 81 & 42.8 & 11.73 & 6.5 \\
$\mathrm{~T}_{3}$ & 11.26 & 20.27 & 10.93 & 9.57 & 88.75 & 39.61 & 10.44 & 4.25 \\
$\mathrm{~T}_{4}$ & 11.2 & 20.22 & 10.86 & 9.49 & 90.5 & 39.44 & 10.39 & 4.63 \\
CD at 5\% level & 0.21 & 0.31 & 0.14 & 0.19 & 1.87 & 0.61 & 0.26 & 0.24 \\
of significance & & & & & & & & \\
\hline
\end{tabular}

The inoculation of Pseudomonas strains significantly reduced the days taken for the appearance of first flower over control. Present findings are in conformity with the findings of Kumari et al. (2015) who reported that the plant growth promoting $P$. fluorescence produced the plant growth regulators like gibberellins, cytokinin and indole acetic acid and these growth regulators promoted early flowering in plants. The results indicated a significant increase in fresh and dry weight and runners of strawberry plants (Table 1) inoculated with Pseudomonas strain CP109 than the un-inoculated control plants. Prathibha and Siddalingeshwara (2013) also reported that increase in fresh weight and dry weight of sorghum plants might be due to the augmentation of total carbohydrates and total soluble protein with the application of Bacillus subtilis and $P$. fluorescence on seeds of sorghum plant.

Root inoculation of strawberry plants with Pseudomonas strain CP109 showed significantly positive effect on all the yield parameters, i.e., number of fruits per plant, fresh weight of fruit, size of fruits (length and breadth), yield of fruit and moisture content in fruit (Table 2). The maximum number of fruits per plant, fresh weight of fruits, size of fruits (length and breadth), yield of fruits and moisture content in fruits was obtained in plants inoculated with Pseudomonas strain CP109. Similar results were reported by Burr et al. (1978) who reported that increase in yield of tubers in potato might be due to the suppression of population of various parasitic and non-parasitic pathogens in the rhizosphere and alter in composition of bacterial flora in soil by the Pseudomonas. Suresh and Hassan (2001) reported highest fruit weight and finger size in banana inoculated with plant growth promoting rhizobacteria. Gopal (2004) found that increase in yield of aswagandha with PGPR inoculation might be due to the proliferation of root, which increase the mineral uptake and dry matter production and Gravel et al. (2007) obtained the highest yield in tomato inoculated with Pseudomonas putida, which might be due to the synthesis of IAA by rhizobacteria, which involved in tomato fruit development, especially during early fruit setting stage. The findings also confirm the findings of Chandra (2014) who obtained maximum number 
of fruits and fruit volume in papaya, which might be due to better plant growth by the inoculation of Pseudomonas striata along with application of NPK fertilizer.

Table 2. Effect of different Pseudomonas strains on yield and yield related parameters of strawberry.

\begin{tabular}{lccccc}
\hline $\begin{array}{l}\text { Treatment/ } \\
\text { observations }\end{array}$ & $\begin{array}{l}\text { No. of } \\
\text { fruits/plant }\end{array}$ & $\begin{array}{c}\text { Average wt. } \\
\text { of fruit }(\mathrm{g})\end{array}$ & $\begin{array}{c}\text { Length of fruit } \\
(\mathrm{mm})\end{array}$ & $\begin{array}{c}\text { Breadth of } \\
\text { fruit }(\mathrm{mm})\end{array}$ & $\begin{array}{c}\text { Yield of fruit/ } \\
\text { plant }(\mathrm{g})\end{array}$ \\
\hline $\mathrm{T}_{0}$ & 19.75 & 9.60 & 38.37 & 27.46 & 189.5 \\
$\mathrm{~T}_{1}$ & 19.5 & 9.89 & 38.82 & 27.85 & 193.56 \\
$\mathrm{~T}_{2}$ & 21.25 & 10.35 & 39.86 & 28.5 & 220.12 \\
$\mathrm{~T}_{3}$ & 18.5 & 9.31 & 38.07 & 27.15 & 172.24 \\
$\mathrm{~T}_{4}$ & 18.75 & 9.25 & 37.91 & 27.06 & 173.44 \\
$\mathrm{CD}$ at $\mathrm{p}<5 \%$ & 0.24 & 0.19 & 0.29 & 0.21 & 2.31 \\
\hline
\end{tabular}

The quality of fruits in terms of total soluble solids, ascorbic acid and anthocyanin content increased significantly with the application of different Pseudomonas strains in strawberry plants. The maximum TSS, ascorbic acid and anthocyanin contents (Table 3) were recorded in fruits of strawberry plants inoculated with Pseudomonas strain CP109. An increase in TSS by the inoculation of plant growth promoting bacteria might be due to the quick metabolic transformation of starch and pectin into soluble compounds and rapid translocation of sugars from leaves to the developing fruits (Tripathi et al. 2016). The maximum titratable acidity was recorded in the berries, which were harvested from un-inoculated plants and minimum acidity was recorded in

Table 3. Effect of different Pseudomonas strains on quality of strawberry fruits.

\begin{tabular}{lccccc}
\hline $\begin{array}{l}\text { Treatment/ } \\
\text { observations }\end{array}$ & $\begin{array}{c}\text { TSS } \\
(\%)\end{array}$ & $\begin{array}{c}\text { Acidity } \\
(\%)\end{array}$ & $\begin{array}{c}\text { Ascorbic acid } \\
(\mathrm{ml} / 100 \mathrm{ml})\end{array}$ & $\begin{array}{c}\text { Anthocyanin content } \\
(\mathrm{ml} / 100 \mathrm{ml})\end{array}$ & $\begin{array}{c}\text { Moisture } \\
\text { content }(\%)\end{array}$ \\
\hline $\mathrm{T}_{0}$ & 6.6 & 0.82 & 39.67 & 40.67 & 94.16 \\
$\mathrm{~T}_{1}$ & 7.28 & 0.79 & 40.97 & 41.81 & 93.83 \\
$\mathrm{~T}_{2}$ & 7.39 & 0.77 & 41.59 & 42.66 & 93.22 \\
$\mathrm{~T}_{3}$ & 6.29 & 0.85 & 39.25 & 40.2 & 94.34 \\
$\mathrm{~T}_{4}$ & 6.26 & 0.86 & 38.7 & 39.9 & 94.43 \\
$\mathrm{CD}$ at $\mathrm{p}<5 \%$ & 0.06 & 0.001 & 1.12 & 1.32 & 0.05 \\
\hline
\end{tabular}

Pseudomonas strain CP109 inoculated plants. The content of ascorbic acid and anthocyanin in strawberry fruits was highest when the plants were inoculated with Pseudomonas strain CP109. The respective increase in ascorbic acid and anthocyanin content might be due to the increased efficiency of microbial inoculants to fix atmospheric nitrogen and secrete growth promoting substances, which accelerated the physiological process like carbohydrates synthesis. The results are in conformity with the findings of Attia et al. (2009) in guava.

The results of present experiment indicated that root inoculation of strawberry plants with beneficial rhizobacteria (Pseudomonas strains JMM19, WHA87 and CP109) positively influenced different growth, yield and quality parameters. These Pseudomonas strains could reduce the application of fertilizers required for strawberry cultivation. Therefore, application of biofertilizers along with optimum quantity of chemical fertilizers in this crop can be safer, economical and ecofriendly technology. Among the different microbial inoculants used in this study Pseudomonas 
strain CP109 strain showed highest increases for growth, yield and quality on Chandler variety of strawberry under Northen Haryana conditions.

\section{References}

AOAC 1990. Official Methods of Analysis, 15th Edn. Association of Official Analytical Chemist, Washington, D.C.

Attia M, Ahmed MA and El-Sanbaty MR 2009. Use of biotechnologies to increase growth, productivity and fruit quality of Moghrabi banana under different rates of phosphorus. World Journal of Agricultural Science 5: 211-220.

Burr TJ, Schroth MN and Suslow TV 1978. Increased potato yields by treatment of seed spieces with specific strains of Pseudomonas fluorescens and P. putida. Phytopathology 68: 1377-1383.

Chandra KK 2014. Growth, fruit yield and disease index of Carica papaya L. inoculated with Pseudomonas straita and inorganic fertilizers. Journal of Biofertillizers and Biopesticide 5:1-4.

Choudhary S and Trivedi PC 2008. Biofertilizers: Boon for Agriculture. In: Biofertilizers. Pointer Publishers, Jaipur, pp. 1-38.

De Silva A, Moore J and Patterson K 2000. Growth promotion of high bush blueberry by fungal and bacterial inoculants. HortScience 35: 1228-1230.

Gopal H 2004. Development of microbial consortium for improvement of growth, yield and alkaloid content of ashwagandha (Withania somnifera Dunal). Journal of Herb Spices and Medicinal Plants 8: 38-43.

Gravel V, Antoun H and Twedde RJ 2007. Growth stimulation and fruit yield improvement of greenhouse tomato plants by inoculation with Pseudomonas putida or Trichoderma atroviride: Possible role of indole acetic acid (IAA). Soil Biology and Biochemistry 39: 1968-1977.

Khandelwal A and Sindhu SS 2013. ACC deaminase containing rhizobacteria enhances nodulation and plant growth in clusterbean (Cyamopsis tetragonola L.). Journal of Microbiology and Research 3:117-123.

Kumari A, Goyal RK, Choudhary M and Sindhu SS 2015. Response of single and co-inoculation of plant growth promoting rhizobacteria on growth, flowering and nutrient content of chrysanthemum. The African Journal of Microbiology Research 9: 1896-1906.

Marques APGC, Pires C, Moreira H, Rangel AOSS and Castro PML 2010. Assessment of the plant growth promotion abilities using Zea mays as indicator plant. Soil Biology and Biochemistry 42: 1229 .

Paramanick KK, Kishore DK and Sharma SK 2005. Commercial strawberry cultivation in the nurseries as well as urban areas in India. Advances in Horticulture Science 19: 34-41.

Prathibha KS and Siddalingeshwara KG 2013. Effect of plant growth promoting Bacillus subtilis and Pseudomonas fluorescence as rhizobacteria on seed quality of sorghum. International Journal Current Microbiology and Applied Sciences 2: 11-18.

Sheoran OP 2004. Statistical Package for Agricultural Research Workers. CCS Haryana Agricultural University, Hisar. http://hau.ernet.in/.

Sindhu SS and Sharma R 2019. Plant growth promoting rhizobacteria (PGPR): a sustainable approach for managing soil fertility and crop productivity. (Malik, D.K. ed) (In press).

Sindhu, SS, Verma N, Dua S and Chaudhary D 2010. Biofertilizer application for growth stimulation of horticultural crops. Haryana Journal Horticulture Science 39(1-2): 48-70.

Singh A, Patel RK, De LC and Pereira LS 2008. Performance of strawberry (Fragaria $\times$ ananassa) cultivars under sub-tropics of Meghalaya. Indian Journal of Agricultural Science 78: 575-80.

Suresh CP and Hassan MA 2001. Studies on the response of Dwarf Cavendish banana Musa AAA to biofertilizer inoculation. Horticulture Journal 14: 35-41.

Tripathi VK, Kumar S, Kumar K, Kumar S and Dubey V 2016. Influence of Azotobacter, Azospirillum and PSB on vegetative growth, flowering, yield and quality of strawberry cv. Chandler. Progressive Horticulture 48: 48-52. 
Wani PA, Khan MS and Zaidi A 2007. Synergistic effects of the inoculation with nitrogen-fixing and phosphate-solubilising rhizobacteria on the performance of field-grown chickpea, Journal of Plant Nutriion and Soil Science 170: 283-287.

Wolfe AH and Patz JA 2002. Reactive nitrogen and human health: acute and long-term implications. Journal of Environment 31: 120-125.

(Manuscript received on 1 June, 2019; revised on 15 April, 2020) 